\title{
"EM TUDO AMAR E SERVIR": Repercussões da Escola Santo Afonso entre a população teresinense
}

\author{
Claudia Cristina da Silva Fontineles* \\ Víviam Cathaline de Sousa Ferreira**
}

RESUMO: O presente artigo analisa o processo da implantação da Escola Agrícola Santo Afonso Rodriguez (EASAR), na cidade de Teresina, bem como ressalta como esta instituição alterou a dinâmica dos projetos de vida dos sujeitos que viviam na região, tendo se configurado como um instrumento essencial à oferta de serviços básicos e culturais para esta comunidade que, à época, localizava-se no povoado Socopo, atualmente, um bairro da capital piauiense. Por meio de fontes hemerográficas, imagéticas e orais e adotando a metodologia de história oral, o estudo apresenta a escola como um lugar de memória, segundo as acepções de Pierre Nora, que se constitui enquanto lugar de pertencimento na memória coletiva do grupo social analisado.

PALAVRAS-CHAVES: História; Memória; Teresina; Escola Santo Afonso Rodriguez.

\section{"In everything love and serve" \\ Repercussions of the Escola Santo Afonso among the population of Teresina}

ABSTRACT: This article has the intention of analyzing the process of implantation of the Escola Agrícola Santo Afonso Rodriguez (EASAR), in the city of Teresina, as well as bounce how this institution changed the dynamics of the life projects of the people who lived in the region, they had to become an essential tool for the provision of basic and cultural services for this community at that time, the school was located in the village of Socopo, currently a neighborhood in the capital of Piauí. Through hemerographic, imagery and oral sources and adopting the methodology of oral history, this study presents the school as a place of memory, according to Pierre Nora's meanings, which constitutes itself as a place of belonging in the collective memory of the analyzed social group.

KEYWORDS: History; Memory; Teresina; Escola Santo Afonso Rodriguez.

\section{"Em tudo amor y sirve": \\ Repercusiones de la escuela Santo Afonso entre la población teresiniana}

RESUMEN: Este artículo analiza el proceso de implementación de la Escuela Agrícola Santo Rodriguez (EASAR), en la ciudad de Teresina, además de enfatizar cómo esta institución ha cambiado la dinámica de los proyectos de vida de los sujetos que vivían em la región, teniendo se configuró como una herramienta imprescindible para la prestación de servicios básicos y culturales para esta comunidad, que en ese momento estaba ubicada en la vereda Socopo, actualmente barrio de la capital Piauí. A través de fuentes hemerográficas, imaginarias y orales y adoptando la metodología de la historia oral, el estudio presenta a la escuela como un lugar de memoria, según los significados de Pierre Nora, que se constituye como un lugar de pertenencia en la memoria colectiva del grupo social analizado.

PALABRAS LLAVE: Historia; Memoria; Teresina; Escuela Agrícola Santo Afonso Rodríguez.

\footnotetext{
* Doutora em História pela Universidade Federal de Pernambuco. Atualmente é professora do Departamento de História, do Programa de Pós-Graduação em História da Universidade Federal do Piauí. Contato: Campus Universitário Ministro Petrônio Portella, Ininga, CEP: 64049-550Teresina-PI, Brasil. E-mail: cfontinelles@gmail.com. ORCID: http://orcid.org/0000-0001-5398-0354

**Mestre em História do Brasil pela Universidade Federal do Piauí. Atualmente é Professora da educação básica na rede privada de ensino de Teresina. Contato: Rua São Francisco, 5039, Socopo, CEP: 64.063-630, TeresinaPI, Brasil. E-mail: vcathaline@gmail.com. ORCID:http://orcid.org/0000-0002-3477-7489
} 
O objetivo do presente artigo é analisar o processo da implantação da Escola Santo Afonso Rodriguez (EASAR), localizada no bairro Socopo, região que na década de 1960, quando da implantação da escola, pertencia ao perímetro rural de Teresina-PI. Objetivamos também analisar como a presença da EASAR alterou a dinâmica dos projetos de vida dos sujeitos envolvidos na pesquisa, configurando-se como um instrumento essencial no que diz respeito à oferta de serviços básicos e culturais para essa comunidade.

Neste artigo, analisaremos as décadas de 1960 e 1970, uma vez ter sido ainda nos primeiros anos da década de 1960 que se estabeleceu o contato entre o arcebispo de Teresina da época, Dom Avelar Brandão Vilela e o Provincial da Companhia de Jesus ${ }^{2}$, residente na Bahia. Na ocasião, foi realizado o convite por parte do bispo para que missionários jesuítas pudessem assumir a direção de um colégio mantido pela Diocese: Colégio São Francisco de Sales (Diocesano) ${ }^{3}$. O nosso interesse em falarmos da atuação da Igreja Católica e da sua relação com a sociedade teresinense é destacar como essa iniciativa do arcebispo foi primordial para o processo de retorno dos jesuítas ao Piauí, e, consequentemente, para a fundação da EASAR.

Desse modo, com a efetivação da transferência e retorno dos jesuítas ao estado, estes iniciaram novas atividades no Diocesano, bem como realizaram novos investimentos na cidade, dentre os quais destacamos a instalação da EASAR. A pesquisa estende-se à década de 1970, período em que a Escola Agrícola Santo Afonso Rodriguez oportunizou a algumas famílias a posse de terras em suas mediações, espaço que, anos depois, tornar-se-ia a região mais populosa do bairro Socopo.

Procuramos inserir a instalação de uma escola jesuíta no povoado na configuração histórica que a forjou, afinal de contas, "historicizar uma instituição educativa implica compreender, sobretudo, as circunstâncias históricas e as relações estabelecidas com a comunidade no processo de sua constituição" ${ }^{4}$. Sabendo disso, nossa investigação partirá de uma análise do contexto político e educacional em âmbito local e nacional. Uma vez que, ancorados nas contribuições de Dominique Julia (2001), sobre estudos voltados à cultura escolar, entendemos que, para que possamos obter uma compreensão razoável do que poderia significar, naquele contexto, a criação de uma escola financiada por recursos de uma instituição religiosa tão tradicional como a Companhia de Jesus, é necessário articularmos a cultura escolar com o conjunto das demais culturas contemporâneas, a citar, a cultura religiosa, política e popular. 
Ainda Dominique Julia, sistematizando e elaborando propostas de entendimento do objeto cultura escolar, informa que podemos partir de um eixo muito importante para a compreensão de uma instituição escolar, aquele que se refere às normas e finalidades que regem a escola. Propositalmente, neste texto, as finalidades assumirão o foco principal do nosso interesse de pesquisa.

Para atingirmos tais objetivos, adotamos como fontes os seguintes documentos: matérias do jornal $O$ Dia, publicação organizada pelo colégio São Francisco de Sales, denominada Diocesano: 90 anos educando para a beleza da paz, documentos oficiais como o Plano de Desenvolvimento Local Integrado de Teresina (PDLI), fontes imagéticas e relatos orais de três ex-estudantes da EASAR (sendo dois deles do regime de semi-internato e um do turno de aulas convencionais) e de uma moradora, mãe de um dos ex-estudantes. Essas fontes foram organizadas e produzidas a partir da adoção da metodologia da História Oral, que entende as memórias dos narradores como documentos "provocados" pelo historiador interessado pelo tempo presente e que corrobora o pensamento proposto por François Bédarida, de que a realidade histórica deve ser vista como uma mistura complexa de objetividade e subjetividade que perpassa a produção do saber histórico ${ }^{5}$. Dessa maneira, as narrativas orais, acionadas pelos historiadores através da metodologia da história oral, mediadas pela memória, apresentam-se como valiosas e singulares tramas que contam sobre um tempo pretérito e, inevitavelmente, constroem possíveis atualizações desse passado.

\section{Retorno das atividades jesuítas ao Piauí}

No Brasil, assim como em toda a América Latina, a atuação da Igreja Católica remonta ao período colonial. Desde então, a relação da Igreja com a sociedade se efetivou a partir de sua aliança com os poderes políticos e não diretamente com o povo; ao contrário, de acordo com a historiografia do tema, esse contato, por vezes, foi de extrema violência física e simbólica. O sistema de Padroado, que significava o pacto da Igreja com o Estado, para que este último pudesse prover as demandas da Igreja no Brasil, é a prova maior dessa aliança. De acordo com Leonardo Boff (1981), mesmo com o fim desse sistema, a Igreja no Brasil continuou atuando em proximidade com as classes dominantes, em detrimento dos interesses das camadas populares. Expressão disso é o fato de que fora a Igreja a principal responsável pela educação dos filhos das famílias ricas por muitos anos no Brasil, mesmo durante o período republicano, após a extinção do Padroado. 
No início do século XX, prevalecia na instituição Igreja o discurso do seu caráter não político, embora suas práticas contradissessem essas declarações. Suas ações, sobretudo as educacionais, implicavam diretamente na conservação dos arranjos sociais e políticos no país. Enquanto instituição que também se responsabilizava pela educação, ela se constituía como uma reprodutora dos sistemas sociais e políticos vigentes.

Nesse contexto, no Piauí e, mais especificamente, na capital Teresina, a ação da arquidiocese, desde sua implantação no Bispado de D. Joaquim Antonio de Almeida, em 1906, "situava-se no projeto de realização de uma presença mais efetiva da Igreja na formação escolar da população piauiense" ${ }^{\text {. }}$. A partir de então, o que os textos produzidos pela historiografia local destacam é que houve um "esforço discursivo da igreja católica em Teresina para se adequar ao contexto da Neocristandade corrente no Brasil, entre os anos 1948-1960"7. Assim, a Igreja no Piauí tinha alcance e projeção social tanto por meio das instituições de ensino que criou (como o Colégio Diocesano e o Colégio Sagrado Coração de Jesus $^{8}$ ), como através dos discursos proferidos no Jornal $O$ Dominical, que, de acordo com Luciana de Lima Pereira, era produzido e divulgado para propagar os anseios morais e políticos que a hierarquia clerical desejava difundir no meio sociopolítico teresinense.

Estudos de Boff, entretanto, destacam que, a partir dos anos 1960, o modelo de Igreja em toda a América Latina começou a se transformar, uma vez que a grande maioria dos cristãos "assimilou o Vaticano II $^{9}$ e fez a virada que se exigia em termos de mentalidade teológica (teoria) e de presença no mundo (prática) ${ }^{10}$. Este feito teria levado à tomada de consciência dos integrantes da Igreja Católica em relação ao seu papel político. E o que se verificou em toda a América Latina foi um processo no qual inúmeros cristãos se fortaleceram através de organizações e associações voltadas para a libertação do povo pobre e oprimido dessa parte do continente. A efetividade do discurso da Igreja teria se direcionado para combater a opressão econômica, política e cultural que os países desenvolvidos exerciam sobre os que estavam em estágio de subdesenvolvimento.

Inserido nesse contexto, Dom Avelar Brandão Vilela ${ }^{11}$ assumiu o cargo de arcebispo da Arquidiocese de Teresina, o que se configura como um ponto essencial para entender as transformações ocorridas nesse período. Afinal, seu bispado ficou marcado por sua atuação na criação de organizações voltadas para atender aos interesses de grupos específicos da sociedade (Juventude Operária Católica (JOC) e Juventude Agrária Católica (JAC)). Além disso, ele assumira cargos importantes na história da renovação da Igreja Católica no Brasil, tendo, inclusive, participado de todas as sessões do Concílio Vaticano II, sendo o responsável 
pelo retorno da atuação de padres jesuítas na educação piauiense. E estes, por sua vez, foram os responsáveis pela construção e fundação da EASAR no povoado Socopo, tema central deste artigo.

Foi no ano de 1960, na cidade de Teresina, capital do Piauí, que ocorreu uma mudança na direção e no projeto pedagógico do colégio confessional São Francisco de Sales Diocesano - até então, uma instituição escolar que desde sua criação, no ano de 1906, era administrada pela Diocese de Teresina. A novidade foi anunciada no jornal O Dia, ainda no primeiro mês daquele ano, em matéria intitulada "Ideia Feliz", conforme informa o fragmento a seguir:

IDEIA FELIZ - O Sr. Arcebispo de Teresina, D. Avelar Brandão Vilela, além dos vários serviços relevantes que já prestou ao Piauí, acrescentou outro, agora, como seja o de entregar o Colégio 'S. Francisco de Sales' aos jesuítas.

Ideia feliz a do Sr. Arcebispo. Os jesuítas são educadores excelentes. Os colégios deles nos mais diferentes países do mundo são conceituadíssimos. Além de serem cultos e competentes, os jesuítas imprimem em seus educandários ordem e disciplina, sem deixarem de ser afáveis e bondosos com os educandos.

A velha disciplina de arrocho não existe mais nos colégios jesuítas. Eles sabem aliar, como os salesianos, a disciplina com a brandura ${ }^{12}$.

Além de procurar atribuir credibilidade ao caráter educativo da instituição, o periódico enfatiza a dimensão afetiva da prática educativa dos jesuítas, que se aliaria a sua já notória competência no campo disciplinar. Para tanto, o jornal recorre à tradição histórica desses colégios:

A Companhia de Jesus, fundada em 1534, por Santo Inácio de Loiola, especificamente para servir de esteio da igreja católica na luta contra a Reforma Protestante de Lutero e para se tornar o principal baluarte da mesma Igreja na obra grandiosa de propagação da fé cristã na Ásia e nas colônias de Portugal e da Espanha aqui na América, devotou-se também à instrução em todos os graus.

[...]Foi com alegria e desvanecimento, portanto, que recebemos a notícia do estabelecimento dos jesuítas aqui em Teresina, à frente de um colégio, pois, através da leitura e de informações pessoais fidedignas, de há muito admiramos os métodos de ensino, a ação apostolar e a obra educacional dos padres jesuítas. Que eles sejam benvindos à terra de Mafrense. D. Avelar marcou mais um tento na cadeia de benefícios ao nosso Estado ${ }^{13}$.

Esta notícia apresenta a confirmação de que o contato realizado entre o então bispo da Diocese de Teresina, Dom Avelar Brandão Vilela, e o Provincial da Companhia de Jesus, com a intenção de pedir que fossem enviados representantes da Companhia para Teresina para assumirem a direção do colégio São Francisco de Sales, mais conhecido como Diocesano, foi um acontecimento bem-sucedido. Tal acordo se concretizou, então, na data de 13 de março de 1960, quando foi realizada a solenidade oficial de entrega do colégio sobre a responsabilidade da Companhia de Jesus. 
Figura 01 - Solenidade da entrega oficial do Colégio aos jesuítas em 13 de março de 1960

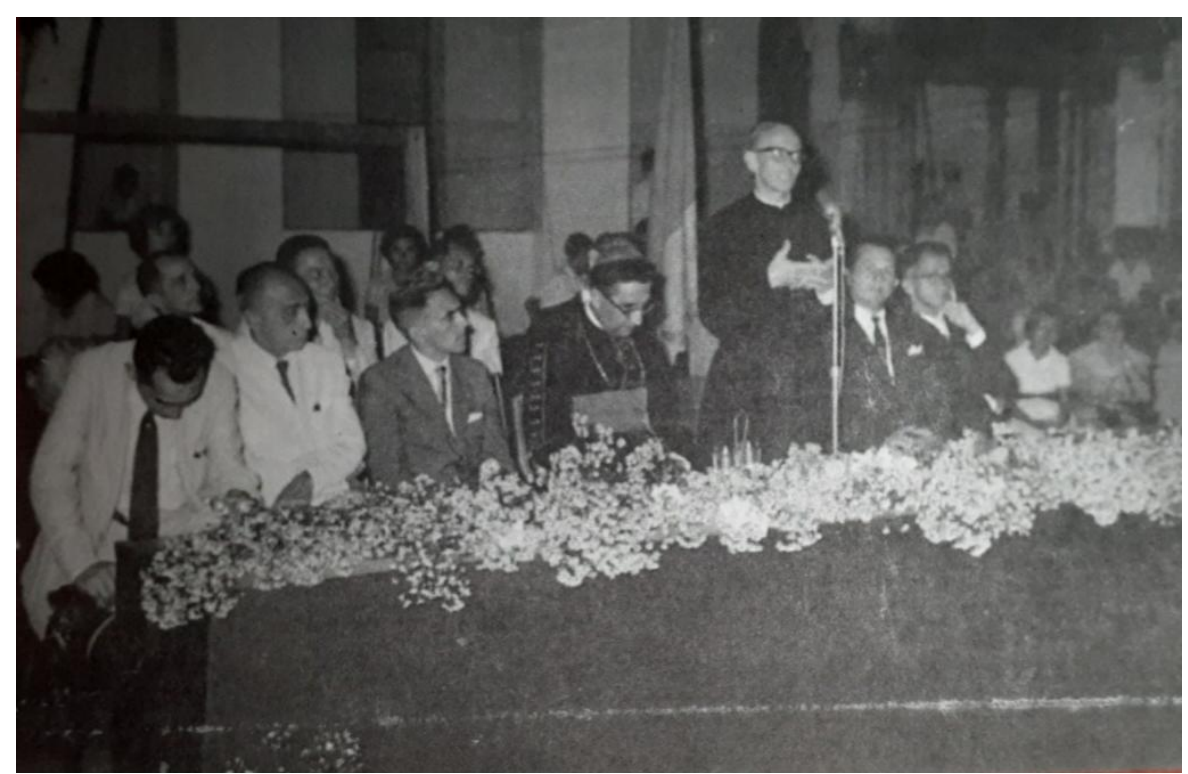

Fonte: DIOCESANO, 1996, p. 35.

Durante a solenidade de entrega do colégio aos padres jesuítas estavam presentes, como é possível observar na fotografia, muitas pessoas. No primeiro plano da imagem, em destaque, identificamos Dom Avelar Brandão Vilela, de cabeça baixa parecendo estar atento ao discurso proferido pelo também religioso, Padre Carlo Bresciani, que naquele momento assumia o cargo de primeiro diretor jesuíta do Colégio São Francisco de Sales. No segundo plano da imagem, percebemos a presença de homens e mulheres adultos, sentados escutando a fala do religioso e, atrás desses que possivelmente eram familiares de alunos ou professores e funcionários da instituição, vemos crianças e/ou jovens, filhos da elite local que, também, possivelmente, eram estudantes na instituição.

A partir de então, a equipe jesuítica que foi enviada para assumir a direção do colégio Diocesano foi composta por três padres e um irmão da ordem: Pe. Carlo Bresciani (diretor e professor de Religião e Latim), Pe. Luciano Ciman (ministro do colégio, professor de Matemática e Religião, diretor do Curso Primário, orientador educacional e padre espiritual dos alunos), Pe. Moisés Fumagalli (vice-diretor e professor de Latim, Francês e Religião) e o Irmão Luis Óboe. Os religiosos se dividiram para cumprir tanto a responsabilidade de administrar a maior escola confessional do estado, quanto de assumir algumas das disciplinas ofertadas na escola. 
Figura 02- Os primeiros padres jesuítas que dirigiram o colégio Diocesano ${ }^{14}$.

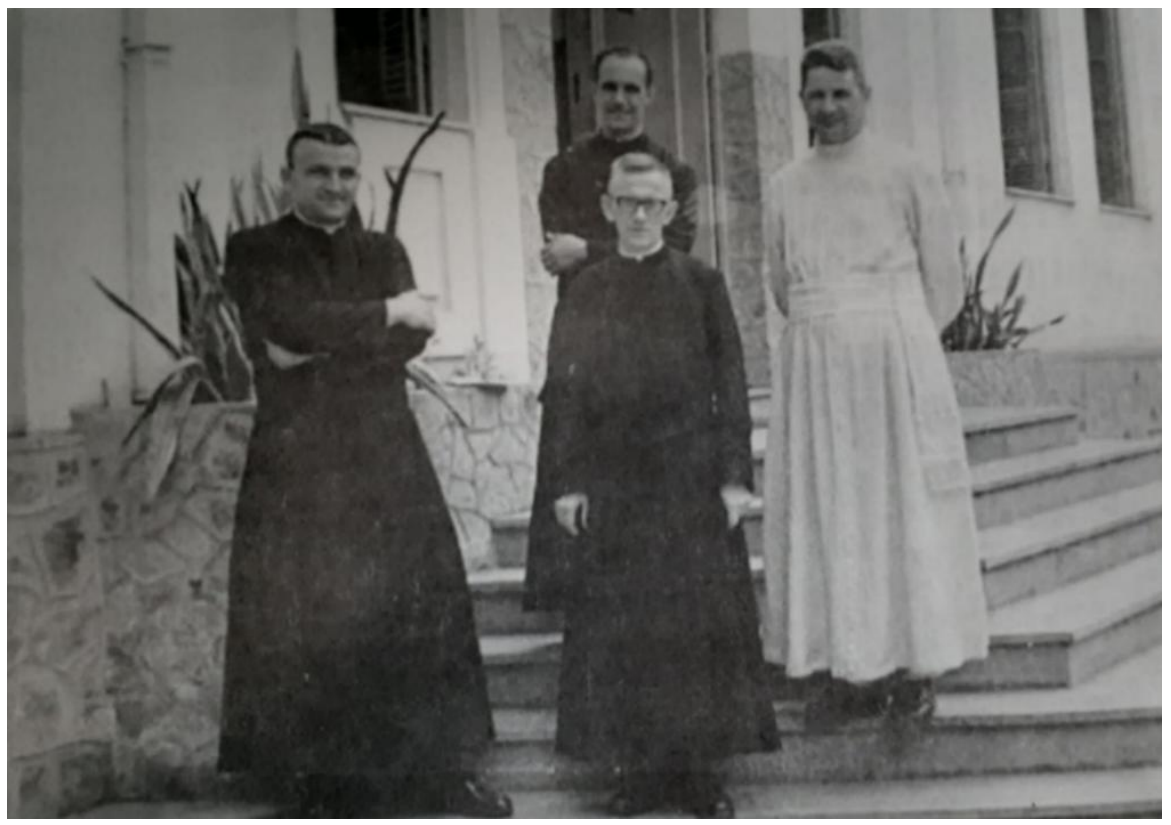

Fonte: DIOCESANO, 1996, p.36.

Remontamos a esse acontecimento para esclarecer que foi a partir do retorno das atividades jesuítas no campo educacional, em Teresina, que foram criadas condições para que uma outra instituição escolar fosse instituída na cidade naquele contexto. Estamos nos referindo à Escola Agrícola Santo Afonso Rodriguez (EASAR).

A EASAR foi fundada em 1963, como parte de uma obra assistencial promovida pelos jesuítas que estavam dirigindo o Colégio Diocesano. Em uma publicação organizada pelo colégio, denominada Diocesano: 90 anos educando para a beleza da paz, e publicada no ano de 1996 para registrar o percurso histórico da instituição, ressalta-se que a fundação da EASAR remonta ao período no qual os jesuítas adquiriram um lote de terra no povoado Socopo, zona rural de Teresina, para ali construírem uma casa de retiros que lhes oportunizasse promover eventos e atividades que aprimorassem a formação intelectual e, sobretudo, religiosa dos educandos e seus familiares, bem como dos funcionários. Além disso, a presença da Companhia na zona rural de Teresina garantiria que os jesuítas alcançassem novos espaços no município e, com isso, consolidassem mais fiéis por meio da educação confessional. Sobre a EASAR, o documento registra que:

A obra (da Casa de Retiros) ficou sob a responsabilidade de Pe. Luciano Ciman ao lado do seu grande colaborador Ir. Luis Óboe que, inteligentemente, instalou oficinas de carpintaria e ferraria. A iniciativa deu oportunidade à redução dos custos da obra e favoreceu trabalho aos jovens que residiam naquela localidade. (...) O trabalho dos jesuítas na Socopo foi 
tomando consistência, avançou muito e deu origem à criação de hortas, fruticultura, granja, fundação da Escola Agrícola Santo Afonso (nome em homenagem ao patrono dos irmãos jesuítas) e à construção de uma paróquia $^{15}$.

A princípio, a publicação alega que foi dado início à construção de uma Casa de Retiros na localidade Socopo, por ela estar afastada do núcleo urbano de Teresina e, dessa forma, poderia proporcionar maior conforto e reclusão durante os retiros que seriam realizados no local. Mas, concomitantemente à construção dessa casa, iniciou-se também a construção de um prédio sede de uma escola que ofertasse educação às famílias daquela localidade. Isto se deu ao mesmo tempo em que os jesuítas, "estrategicamente", aproveitaram o local para instalar oficinas de carpintaria e ferraria, atividades estas que ajudariam na diminuição dos custos da obra e ainda ofereceriam empregos para os jovens que viviam próximo ao local.

Os moldes dessa iniciativa dialogam com os novos princípios e modelos que a Igreja Católica estava assumindo nos anos 1960, mencionados anteriormente neste texto. Aproximar-se dos mais pobres e fortalecer os vínculos com fiéis por meio da educação permite formular vários entendimentos, desde a luta por possibilitar a inclusão das camadas sociais a direitos elementares, até a perspectiva do fortalecimento aos campos de atuação social dos clérigos no seio social, uma vez que um projeto como esse que vislumbrava a criação de um complexo de prédios onde pudessem ser exercidas atividades educacionais e religiosas, entretanto, deve ser analisado a partir dos possíveis interesses (finalidades) que norteavam os próprios objetivos da Companhia de Jesus. Ainda que não possamos afirmar com precisão quais seriam esses objetivos, a fonte anteriormente analisada nos permite inferir que a construção da EASAR concretizou dois grandes fatores que são comuns às obras educacionais erguidas pela Companhia de Jesus ao longo de sua história: primeiro, o de alcançar os fiéis que moram em áreas longínquas ${ }^{16}$ e, segundo, o de ofertar uma educação guiada pelos preceitos do Cristianismo e de acordo com os ensinamentos orientados pelo fundador da Ordem, Santo Inácio de Loyola.

É importante ressaltar como a construção de uma escola confessional na área rural do Município de Teresina configurou-se como um elemento espacial que atraiu pessoas para os seus arredores e, consequentemente, alterou o crescimento do espaço urbano teresinense, contribuindo para seu alargamento em direção aos limites da sua zona leste. Sobre isso, o geógrafo Stanley Braz de Oliveira discute que

a Escola Santo Afonso representava um novo limite espacial da cidade de Teresina, através das práticas espaciais de seletividade e da antecipação espacial. Dessa forma, 


\begin{abstract}
a igreja católica transforma um imóvel situado em um descampado distante de tudo em uma escola de referência educacional, cristalizando mais um símbolo dessa instituição e garantindo um contínuo da valorização do catolicismo. (...) A localização da Escola Santo Afonso proporcionou maior visibilidade à zona leste da cidade, e aos poucos surgiram novos bairros, vias de acesso foram construídas e a cidade de Teresina foi se conturbando com o espaço até então isolado, levando o perímetro urbano de Teresina à escola e fazendo da região um espaço de grande especulação imobiliária e, da escola, um dos maiores fixos e símbolos da Igreja Católica em Teresina ${ }^{17}$.
\end{abstract}

Para o pesquisador, não há dúvidas de que a atuação da EASAR foi fundamental para a transformação do espaço no qual ela foi construída. Ele argumenta que, a exemplo de outras instituições escolares da cidade (Colégio das Irmãs e Diocesano) ${ }^{18}$, a abertura de uma escola em área muito distante do núcleo urbano não explica apenas o interesse da Companhia de Jesus em dissipar a sua fé cristã. Abrir o estabelecimento educacional foi uma demonstração de como a Igreja Católica pôde colaborar para a expansão espacial da cidade, por mais que fosse o caso da EASAR, por ele apontada como uma das "mais tímidas obras confessionais da Igreja Católica em Teresina" ${ }^{\prime 19}$.

O período em que os jesuítas retornaram suas atividades ao Estado do Piauí comumente é reconhecido pelos historiadores como uma fase conturbada do processo de redemocratização da política nacional. Na configuração política, o Piauí e o Brasil eram administrados, respectivamente, pelos mandatos de Francisco das Chagas Caldas Rodrigues e de João Goulart, ambos filiados ao Partido Trabalhista Brasileiro (PTB). Entretanto, foi o conflito ideológico entre posição e oposição (basicamente representada pelos militares de baixo calão e aqueles que atuavam em algum ministério e mesmo os civis contrários às medidas de reforma de base considerada esquerdista, realizadas pelo então presidente), que inviabilizou que o governo de Goulart findasse por vias legais. Antes mesmo que isso ocorresse, os militares realizaram um golpe de Estado, retirando Jango do poder. Após esse acontecimento, diversas transformações foram impostas à sociedade civil, sobretudo, no que diz respeito à educação.

A Escola Agrícola Santo Afonso começou a funcionar na zona rural de Teresina inserida nessa conjuntura política, de transição forçada do poder político nacional e, ao mesmo tempo, da atuação eficiente da Igreja em prol de projetos sociais e educacionais. Sabendo disso, a escola deve ser entendida como um elemento físico que foi construído em um tempo histórico marcado por conflitos ideológicos e transformações estruturais no próprio campo da educação, o que, portanto, só nos permite pensá-la a partir da estrutura social e política da qual fazia parte. 
Nosso propósito, neste texto, é analisar os significados da presença física e simbólica da EASAR no povoado Socopo e, a partir disso, reconhecer as transformações promovidas por ela nesse espaço, naquilo expresso por Ana Fani Carlos, ao declarar que "a forma também está carregada de valor social, faz parte do quadro de referências da vida, por isso, entra no plano da memória, pois os ritmos da vida cotidiana se ligam à duração das formas e de suas funções"20. Assim, desenvolveremos nossa discussão sobre o funcionamento da escola durante seus primeiros anos de existência, demonstrando como a presença daquela instituição no povoado Socopo foi essencial para transformar as vidas dos sujeitos diretamente impactados pela construção da escola.

\title{
A presença jesuíta em Teresina e sua atuação no povoado Socopo (1960-1970)
}

No ano de 1964, a Escola Santo Afonso Rodriguez foi inaugurada, passando a atender os filhos de moradores da comunidade Socopo, bem como os filhos das famílias de moradores de outras comunidades rurais mais próximas, a citar os povoados Santa Luz, Soinho, Baixão do Carlos, Cacimba Velha, dentre outros. A região passou a receber cada vez mais moradores, interessados no ensino ofertado, na infraestrutura e nos serviços básicos em geral.

A escola, assim, passa a ser entendida, nesta pesquisa, como lugar de memória, uma vez que há nos registros das narrativas orais dos sujeitos que foram entrevistados "sinais de reconhecimento e de pertencimento de grupo" 21 . Portanto, entendemos que a escola é, "antes de tudo, restos" de lembranças que ainda sobrevivem na consciência coletiva desses antigos estudantes e trabalhadores ${ }^{22}$.

Evocamos a contribuição dos estudos de Nora, consoante à análise feita por Paul Ricœur:

\begin{abstract}
repousa (..) os três sentidos da palavra (lugar): material, simbólico e funcional. O primeiro fixa os lugares de memória em realidades que consideraríamos inteiramente dadas e manejáveis; o segundo é obra de imaginação e garante a cristalização das lembranças e sua transmissão; o terceiro leva ao ritual que, no entanto, a história tende a destituir, como se vê com os acontecimentos fundadores ou com os acontecimentos espetáculos, e com os lugares refúgios e outros santuários ${ }^{23}$.
\end{abstract}

Sob essa perspectiva, a EASAR, conforme os relatos dos sujeitos entrevistados nesta pesquisa, configura-se como lugar de memória por apresentar, por meio das lembranças, os três sentidos mencionados por Ricœur: o de espaço físico dado e localizável; o de "obra da imaginação", que é capaz de despertar, nos sujeitos que rememoram, algumas lembranças em comum, ou seja, cristalizadas na memória dos indivíduos; e o de lugar de santuário, no 
sentido de ser vista/entendida, por muitos, enquanto um lugar diretamente relacionado a acontecimentos na história do bairro Socopo.

Um exemplo disso são os relatos orais de dona Teresinha da Silva Coutinho ${ }^{24}$, segundo a qual, quando ela chegou à capital, "tudo era mato quando eu cheguei" 25 . Ela, que morava no município vizinho de União, veio com seu esposo e filhos morar na região do Socopo, para ficarem próximos de seus familiares - pelos quais tomaram conhecimento da EASAR -, que já viviam em Teresina, e pela qual se interessaram em matricular sua prole.

No ano de 2013, a moradora informou que residia em sua casa própria há 42 anos, mas que residira antes por sete anos em um terreno cedido pelo proprietário da Sociedade Construtora do Poti. Um dos filhos dessa moradora, o senhor Francisco Coutinho de Sousa ${ }^{26}$, confirmou ter vindo morar na região da grande Socopo, com toda a sua família, por volta do ano de 1967, em busca por acesso à educação formal. Ele disse:

Nasci em 22 de maio de 1962. Aí, com cinco anos de idade, meu pai, por conta da dificuldade, vivia de roça, pensava na gente é, pelo menos é, pelos menos ter um pouco de leitura, naquele tempo o pessoal se preocupava que os filhos tivessem pelo menos um pouco de ensino, não era um estudo é, não sonhava em ser formado, mas pelo menos ter um, soubesse ler alguma coisa assim ${ }^{27}$.

Para Dona Teresinha e sua família, o interesse em migrar era, sobretudo, para modificar o destino da vida que levavam na zona rural de União, município cuja distância do centro de Teresina estava em torno de $65 \mathrm{~km}$ e de $49 \mathrm{~km}$ da região do povoado Socopo. É necessário relacionar que as maiores transformações ocorridas na região ocorreram devido ao processo de migração interna que aconteceu no Piauí, durante as décadas de 1960 e 1970. As peculiaridades da estrutura da produção rural no estado, nesse período, levaram a um processo de transferência dos indivíduos que viviam nas áreas rurais do estado para os centros urbanos, em outros estados da federação ou para a capital.

Dona Teresinha e seu esposo, preocupados com a educação dos filhos, queriam ter a oportunidade de vê-los matriculados em uma boa escola. Dessa maneira, foram atraídos a viver nas terras denominadas como Socopo. Ainda que eles não tenham migrado para o núcleo urbano de Teresina, estabelecer moradia no povoado Socopo traria, então, a expectativa de mudar de vida. "O migrante piauiense, nas áreas urbanas e rurais do Estado do Piauí, está(va) incorporado à 'força de trabalho de reserva'. A maioria deles vive(ia) da esperança de um emprego estável e da eventual proteção da legislação trabalhista brasileira" ${ }^{28}$. A chegada de tantos indivíduos oportunizou um crescimento espacial na capital durante as duas décadas apresentadas e causou o agravamento das contradições sociais dentro 
das áreas urbanas da capital, assim como nas áreas rurais. O exemplo do povoado Socopo dá luz para compreendermos como os contrastes sociais balizaram esse período da nossa história.

A senhora Teresinha destaca o papel da escola entre suas motivações para migrar para a região:

Porque meu marido dizia, porque ele dizia que queria vir pra perto das gentes dele, que a gente dele era aqui na Teresina e na Cajaíba, queria vir pra gente ficar perto deles, aí tinha um colégio perto e aí já tinha três meninos e aí queria botar no colégio $^{29}$.

O filho da senhora Teresinha, Francisco Coutinho, relata sobre a região da Socopo quando chegaram em Teresina:

Aí nós viemos de lá, em 67, eu já tinha cinco anos de idade, meu pai veio para cá, pra, nesse tempo Teresina era pequena, então Socopo seria uma zona rural, era aqui mesmo onde nós chegamos, aqui não tinha loteamento, não tinha nada, nós fomos ser agregado do latifundiário, que seria o Dr. João de Deus Fonseca, em $67^{30}$.

As seleções das datas, como já mencionado, foram feitas a partir das escolhas das memórias de cada entrevistado. Dona Teresinha destacou a data a partir de quando obteve a casa própria. Isso talvez indique que essa moradora só tenha se considerado residente da capital quando passou a residir em uma residência de propriedade de sua família, indicando o significado que essa conquista teve em sua vida e em sua forma de contar sua história. O certo é que a família inicialmente foi morar em um terreno cedido a eles na região, que não corresponde ao mesmo em que residem atualmente. Ainda segundo Francisco Coutinho:

A minha mãe, o sonho dela era de ter um lote, um terreno para ela morar com a família, morando agregado do João de Deus. E ela criou um laço de amizade muito grande aqui no colégio né, com a direção, com os superiores aí do colégio jesuíta né, porque esse colégio aí é jesuíta né. Aí ela falava muito para um senhor chamado Irmão Mantieiro, que o sonho dela era, porque meu pai já trabalhava aí no colégio né, e ela tinha aquele contato né, sei lá, conversando, se encontrando, nas missas, nas reuniões de família, aí ela falou que tinha vontade de comprar, de ter um lugar para morar $^{31}$.

Esse relato permite notar a relação desses moradores com os padres e outros integrantes jesuítas que dirigiam a escola, evidenciando um convívio próximo, em que os religiosos ministravam missas e/ou encontros religiosos na comunidade, onde se reuniam com as famílias, demonstrando ser solícitos e envolvidos com o bem-estar desses moradores. Francisco Coutinho continua nos explicando essa relação, destacando a importância de um desses jesuítas, o Ir. Mantieiro ${ }^{32}$, para a sua família. 
Aí ele mandou ela procurar o Doutor João, se ele não tinha algum terreno para vender, que o colégio comprava e cedia para ela ir pagando aos poucos, descontando na folha de pagamento do esposo dela, isso em 1972, mais ou menos. Aí foi um pouco dificultoso. Aí um dia o Irmão Mantieiro, que era o diretor chefe daqui do colégio, se encontrou com o Doutor João. Doutor João já tinha, isso Doutor João já tinha cedido o terreno aqui do Santo Afonso, o Doutor João doou para os jesuítas, isso lá em 1958. Aí o Doutor João, o Ir. Mantieiro, conversando com o Dr. João, tocaram no assunto de comprar uma quantia de terra e dividir com os funcionários que trabalhavam nos serviços gerais, serviço grosseiro aqui do colégio, para morarem próximo daqui do colégio. Aí eles chegaram a essa conclusão de comprar essa tira de terra, que ela dá mais ou menos um $700 \mathrm{~m}$ por $50 \mathrm{~m}$ de largura, e dividiram em lote para os funcionários, aí a mamãe, ele cedeu dois lotes para minha mãe pagar descontando em folha de pagamento e com isso ele disse que se ela quisesse, ele construía uma casa para ela aqui, e construiu essa casa e foi descontando em pagamento, até quando terminou, aí isso foi em 1972. Em 1973 nós nos mudamos pra cá ${ }^{33}$.

Através desse relato, podemos verificar que foi a partir da compra efetivada pelo jesuíta Irmão Mantieiro, na época diretor da Escola Agrícola Santo Afonso Rodriguez, que se iniciou o processo de ocupação da chamada 'Primeira rua' do bairro Socopo, na qual os primeiros moradores a ocupá-la foram os membros da família da Dona Teresinha Coutinho. A rua ficou, então, conhecida como "Primeira-rua" da comunidade Socopo, e teria sido construída pelos moradores que compraram os primeiros lotes por intermédio dos jesuítas, especificamente, do Ir. Montieiro.

O senhor Francisco Coutinho chegou a relatar um momento peculiar desse período, que nos fez refletir sobre o quanto o campo (a natureza, em geral) é esse "lugar de produção e de obras" ${ }^{34}$, sendo a modificação da paisagem natural em paisagem humanizada e urbana ${ }^{35}$ uma dessas obras produzidas pelo homem.

Primeiro, quando foi pra ter uma rua aqui, meu pai pegou uma foice e abriu, fez um caminho aqui, uma vereda, pra lá. Aí pegou um pauzinho véi, pegou uma tábua e botou o nome Rua São Francisco. Lá na entrada [...]. Papai é muito devoto de São Francisco. Tudo dele é com São Francisco pelo meio, então ele fez uma foice e fez a vereda aqui, um caminhozinho, tirou um rumo daqui pra acolá. Aí pegou e botou a estacazinha e escreveu "rua São Francisco". Aí eu disse: "Quando é que isso aqui vai ser rua?". Em 1973. Aí as vezes eu fico me lembrando disso, eu digo, rapaz, quando eu vi isso aqui só o caminho e hoje aqui é asfalto ${ }^{36}$.

A partir dessa iniciativa do Ir. Mantieiro, ao comprar os lotes de terra, outros moradores que já viviam e trabalhavam na região iriam residir nos terrenos loteados. Isso influenciou a organização dessas famílias de trabalhadores da escola, que puderam adquirir lotes de terra durante os primeiros anos da década de 1970, uma conquista de fundamental importância para fixação dessas famílias na região, sendo a primeira vez que lhes era dada a oportunidade de se tornarem proprietários de suas residências. 
A influência da escola na história do povoado Socopo se evidencia com a compra do terreno, às margens dos limites do terreno da própria escola, que foi loteado e vendido para alguns dos funcionários de baixa renda da escola, ou mesmo para outras famílias que já residiam ali próximo e não tinham terreno ou casa própria para morar, oportunizando que estas famílias pudessem ter acesso a uma moradia própria, não necessitando mais viver como sitiantes em terras de latifundiários da região.

É importante salientar que os relatos orais adotados nesta pesquisa devem ser lidos como documentos, nos quais pudemos, através da metodologia da história oral, identificar rastros de um passado recente que envolve a cidade de Teresina, tal como propõe Verena Alberti:

acreditamos que a principal característica do documento de história oral não consiste no ineditismo de alguma informação, nem tampouco no preenchimento de lacunas de que se ressentem os arquivos de documentos escritos ou iconográficos, por exemplo. Sua peculiaridade - e a história oral como um todo - decorre de toda uma postura com relação à história e às configurações socioculturais, que privilegia a recuperação do vivido conforme concebido por quem viveu ${ }^{37}$.

É esta a 'postura com relação à história' que assumimos neste estudo: a que privilegia a seleção e organização da fala de sujeitos que tiveram uma experiência no passado, reconhecendo que, dada a incapacidade de recuperarmos as experiências, acessamos apenas as ressignificações possibilitadas pela memória, que relê e reelabora o vivido, conforme suas possibilidades e interesses.

A demanda por educação escolar esteve entre os principais atrativos de Teresina desde a sua fundação, no século XIX. Em 1969, de acordo com o Plano de Desenvolvimento Local Integrado de Teresina (PDLI) ${ }^{38}$, a capital contava com $64 \%$ da sua população constituída por analfabetos, sendo este cálculo construído numa amostragem total de 205.000 habitantes, dos quais $160.011(78,2 \%)$ residiam na área urbana e 45.990 (21,8\%) na área rural. O Plano informa também que, dentre as 38.869 crianças entre 7 e 14 anos, 69\% frequentavam escolas, sendo que as crianças residentes na zona urbana correspondiam ao triplo das da zona rural. Esses dados confirmam que a instrução escolar ainda se constituía um privilégio para poucos teresinenses, e a situação ficava ainda mais agravada para aqueles que viviam na zona rural do município, levando-se em consideração que a maior parte das escolas se localizava no núcleo urbano.

Os dados explicitam que, mesmo entre a população urbana, que era a maioria no município, o acesso à educação era restrito entre as décadas 1960 e 1970. Isso acentua a importância atribuída aos serviços educacionais oferecidos pela EASAR numa comunidade da 
zona rural de Teresina, ao oportunizar que os moradores usufruíssem dos serviços da escola e transformassem suas trajetórias de vida.

Nos anos 1970, com a escola em pleno funcionamento, várias foram as crianças que tiveram seus projetos de vida atrelados ao projeto educacional ofertado pela EASAR. Uma das atividades que marcou diretamente a vida do entrevistado Francisco Coutinho foi a implantação da oficina de marcenaria, afinal, ele diz atuar atualmente neste ramo para prover o sustento da sua família, e relembrou com certa nostalgia dos anos de sua infância, quando iniciou nos aprendizados da área no curso que a escola oferecia:

Era o seguinte, a gente estudava de manhã, aí você sabe, aluno na sala era homem e mulher, nos cursos de marcenaria, tinha a área de marcenaria que era para um lado, tinha a área de corte e costura que era em outros lugares, então a gente só se encontra na hora do lanche e meio-dia para o almoço. [...] rapaz aí era a minha infância, minha infância no Santo Afonso, a gente passava o dia, aí, o dia pra gente era pequeno, a gente achava pequeno o tempo, porque a gente achava aquilo ali como uma coisa que, sei lá, muito gostoso, você estudava de manhã, você jogava futebol ou qualquer outro tipo de diversão ${ }^{39}$.

As aulas dos cursos, mencionadas no relato, eram ofertadas no contraturno das aulas normais. Dessa maneira, os estudantes tinham na sua rotina as atividades de aulas do currículo regular em um turno e no contraturno participavam das chamadas "escolas-oficinas". A escola, portanto, tinha um regime de semi-internato. Durante o tempo que ficavam na escola, os estudantes recebiam lanche e almoço para permanecer na instituição durante o dia todo, não precisando retornar para suas casas. Isso expressava outra intervenção na rotina dos estudantes, haja vista as merendas oferecidas pela escola auxiliarem no desenvolvimento dos aprendizes e atenuarem o orçamento familiar. A fotografia que segue, retirada do acervo particular da professora da instituição, Conceição Rodrigues ${ }^{40}$, registra a presença desses estudantes no local em que recebiam os alimentos e demonstra o número expressivo de educandos: 
Figura 03 - Estudantes em fila para receberem a merenda escolar.

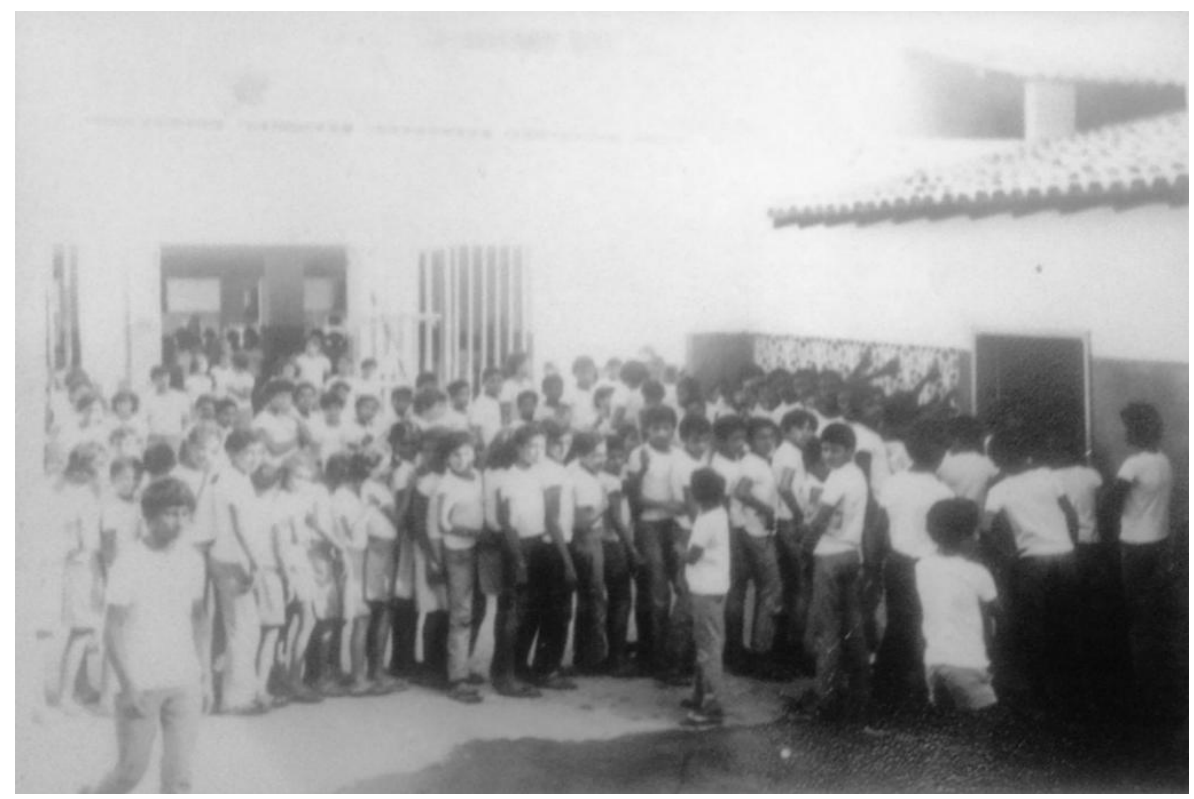

Fonte: Acervo da professora Conceição Rodriguez.

Boa parte dos educandos que tiveram suas imagens capturadas nesse registro fotográfico passavam o dia na escola, desenvolvendo atividades, tanto no trato com hortaliças, quanto nos cursos das escolas-oficinas (serigrafia, marcenaria, serralharia, bordado). A maioria dessas crianças era oriunda de famílias pobres da região, cujos pais trabalhavam no cultivo de roça e na criação de animais. Participar dessas atividades era a possibilidade de aprenderem um ofício, que poderiam executar junto aos seus pais lavradores ou ainda de seguirem novos rumos profissionais, como é o caso da carpintaria e da marcenaria. $\mathrm{O}$ trabalho que essas crianças aprenderiam, para algumas famílias, era entendido como uma oportunidade de ascensão social. A esse respeito, a moradora Teresinha da Silva Coutinho destaca que:

\begin{abstract}
Mas graças a Deus que os meninos eram interessados, porque aqui teve gente que não deixou os filhos, porque disse que não ganhava nada. Eu disse desse jeito: "Não, meus filhos é pra você aprender, só vai sair quando quiser sair, ou quando botarem para fora, mas é pra aprender, porque do quê que a gente vai viver? Não dá pra viver porque não tem um pai... não dá quase nada na roça, então tem que aprender mesmo e aí que é pra fazer as coisas, pra depois ficar trabalhando, porque serviço de carpinteiro nunca falta, num é?!" .
\end{abstract}

Todavia, nem todas as crianças que estudavam na escola puderam participar dessas oficinas, algumas porque os pais não aceitavam que elas passassem o dia inteiro na escola, em regime de semi-internato, uma vez que não eram atividades obrigatórias, participavam apenas aqueles que as consideravam relevantes. Outros estudantes não participavam, porque precisavam ajudar no serviço de casa. Isso acontecia, sobretudo, com as meninas, que, muitas 
vezes, não eram liberadas pela família para participarem dos cursos de corte e costura ou de bordado, ofertados para elas. Uma ex-estudante da escola, Vilani de Sousa Mota ${ }^{42}$, fala sobre o motivo de ela não ter podido participar dessas atividades:

A única coisa que eu me recordo que não consegui participar na Escola Santo Afonso Rodriguez foi dos cursos, cursos que tinha lá, não é nem técnico, era curso de costura, crochê, serralharia, marcenaria. Ele oferecia tanto curso para homens quanto pra mulher, né, pra adolescentes, e eu nunca participei. A única coisa do Santo Afonso que eu lembrei que eu não participei foi desses cursos que tinha.[...] Como a minha mãe, só morava eu e minha mãe e meus irmãos, e a minha mãe trabalhava, nem sempre tinha alguém pra ficar com meus irmãos, meus irmãos eram menores e eu a mais velha, então eu tinha que ficar. Como eu estudava à tarde, quando iniciou os cursos, eu tava estudando. À tarde, foi da $5^{\mathrm{a}}$ à $8^{\mathrm{a}}$ série e os meus irmãos estudavam pela manhã, aí eu tinha que deixá-los, pegá-los e ainda ficava em casa fazendo o almoço, e como os cursos eram ofertados todos pela manhã, não tive como frequentá-los ${ }^{43}$.

Não frequentar esses cursos, muitas vezes, não se tratava de uma escolha. Segundo ela, essa foi a única atividade da qual ela não pôde participar na escola, porque ela deveria cumprir com os deveres do lar, por ser a irmã mais velha e ter que cuidar dos irmãos mais novos, enquanto sua mãe, solteira, tinha que trabalhar fora para sustentar a família. Essa moradora continuou explicando como se dava, propriamente, o funcionamento desses cursos na escola: "Por o colégio Santo Afonso ter uma área muito grande, então eles fizeram novas salas, justamente para esses cursos. Chamava-se as oficinas, era o termo que nós chamávamos o local lá de fazer isso, eram as oficinas" ${ }^{\text {"4 }}$. Ou seja, os cursos eram ofertados no turno da manhã, em um espaço que fora construído para abrigar as máquinas que seriam utilizadas nas aulas, tanto as de serigrafia, que ela não pôde participar, quanto as máquinas utilizadas no curso de carpintaria, marcenaria e serralharia, como expõe a fotografia a seguir:

Figura 04 - Um dos galpões construídos para sediar as aulas-oficinas de serralharia e marcenaria.

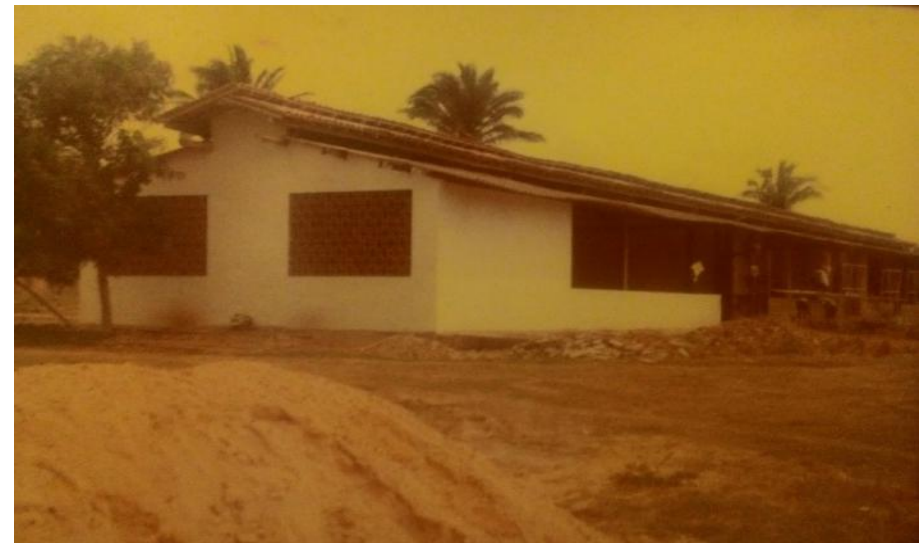

Fonte: Acervo da professora Conceição Rodriguez. 
A ex-estudante Vilani Mota relembra também, talvez por não ter tido vínculo com as atividades exercidas nas oficinas, de outras práticas comuns na escola nesse período:

\begin{abstract}
Da $5^{\mathrm{a}}$ à $8^{\mathrm{a}}$ série eu lembro mais das festividades que eu participava, das quadrilhas que todo ano tinha, tinha quadrilha de todas as séries, tinha um dia só que eles tiravam para nós apresentarmos para eles e para comunidade. E lembro de festival de canção, que nós tínhamos, que nós, os alunos, que participávamos. Tinha uma rapaz chamado Luizinho, que ele começou a trabalhar lá e nos incentivou, fazia esses festivais de canção para gente. (..) Era assim, nós mesmos fazíamos a autoria de nossas músicas e íamos apresentar, tinha um ou dois dias para apresentar tanto para escola toda, como para a comunidade e as vizinhas próximas. Era $7 \mathrm{~h}$ da noite que iniciava e ia mais ou menos até $9 \mathrm{~h}$ da noite, era uma evento muito grande e muito bom. Ele formava a banda, nós ensaiávamos bem antes, né, tinha o salão paroquial que a gente passava bem um mês ensaiando com eles lá na banda e tinha os dias da apresentação e as quadrilhas era do mesmo jeito. Teve anos que era assim, três dias seguidos, lá tinha uma campo de futebol muito grande e uma quadra esportiva que lá reunia as comunidades, não era nem só a comunidade Socopo, era as comunidades próximas, tinhamos Soinho, Morros, Pedra Mole. Todos os pais, parentes e amigos participavam dessas festividades. (...) Todos das comunidades participavam, era o nosso lazer, era o lazer das comunidades próximas da Socopo, eram esses eventos da Escola Santo Afonso ${ }^{45}$.
\end{abstract}

No geral, os sujeitos entrevistados recordaram, como foi o caso de Vilani Mota, muito mais das atividades extracurriculares desenvolvidas no interior da Escola, pois estas se configuravam para eles, muitas vezes, como as poucas oportunidades de lazer e de entretenimento. Como viviam longe do centro da cidade, grande parte das práticas culturais que puderam vivenciar na infância e na adolescência se resumiam às festividades inseridas no calendário da escola. Como disposto na memória citada, as festas juninas eram comemoradas com a dança tradicional de quadrilhas e, por muitos anos, ocorreram também festivais de canção, que eram organizados por um prefessor leigo da escola, o qual, de acordo com Vilani, incentivava os estudantes da escola a produzirem suas próprias músicas, a ensaiá-las e divulgá-las junto à comunidade escolar.

A escola, por tudo que já foi abordado neste texto, representava também um dos lugares de sociabilidade mais frequentados/respeitados na comunidade Socopo nos anos 1970, portanto, era um lugar de proximidade e de trocas de experiências, tanto entre os estudantes, quanto destes com os profissionais da educação e seus familiares. Ainda que fosse um espaço privado, a escola recebia, em diversos momentos, visitantes, que não necessariamente faziam parte da comunidade escolar, sobretudo durante algumas festividades que realizava. Além disso, a escola, enquanto local destinado à formação intelectual, religiosa e cultural, também proporcionava vivências diferenciadas para o corpo discente, às quais, muito provavelmente, só eram praticadas/consumidas por esses estudantes no interior da escola, como, por exemplo, a audiência de bandas musicais e de peças teatrais. 
Figura 05 - Banda de músicos da Prefeitura toca no pátio da Escola Santo Afonso, em 1979.

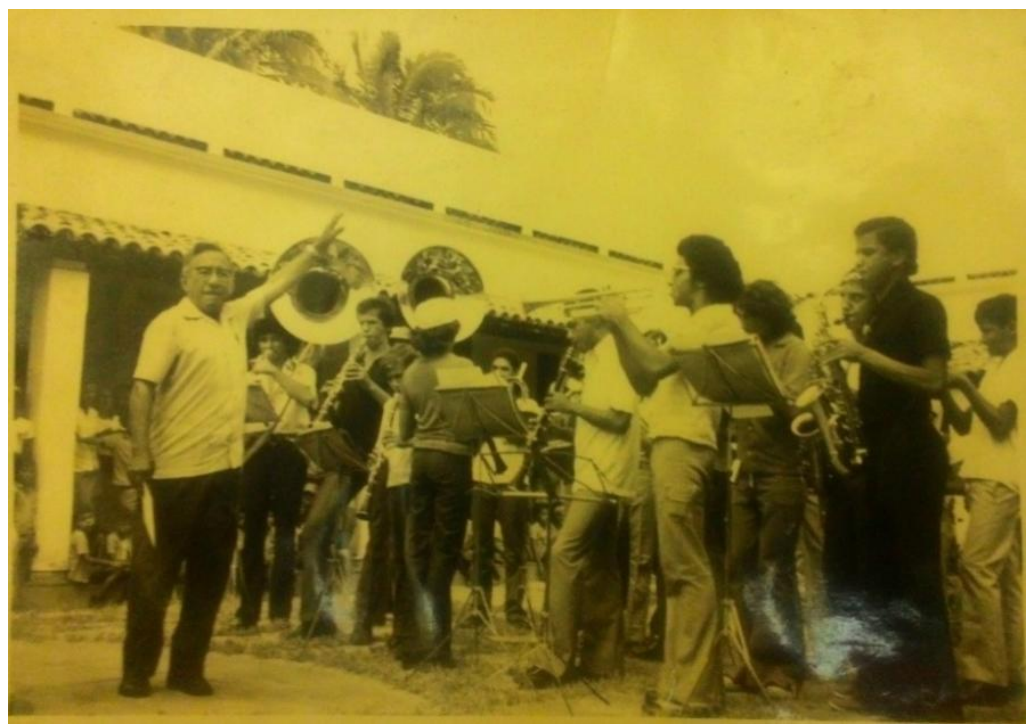

Fonte: Acervo particular da Prof. ${ }^{a}$ Conceição Rodrigues.

A presença da banda de músicos da Prefeitura indica que se tratava de um evento cívico, mais ainda, explicita principalmente o prestígio que a escola tinha junto às autoridades públicas. Além disso, o local de reunião de todos os estudantes era o pátio da escola, era nele que aconteciam os mais variados tipos de solenidades e ritos. Lá também ocorriam missas, uma vez que a comunidade Socopo não dispunha de um prédio que servisse como templo para celebrações católicas. Essas celebrações litúrgicas ocorriam no pátio da escola, conforme foi registrado pela figura 06 .

Figura 06- Missa realizada no pátio central da escola.

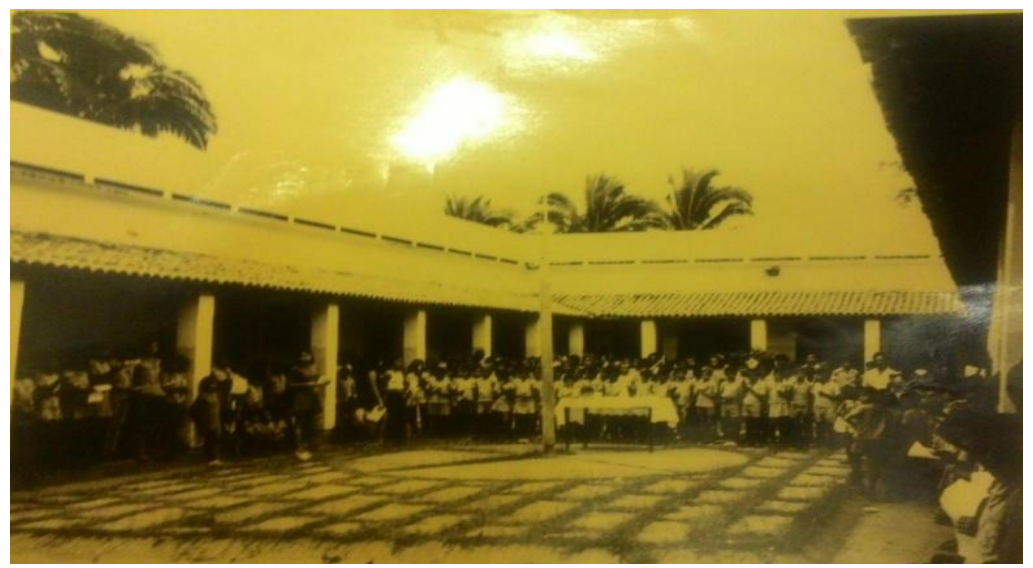

Fonte: Acervo particular da Prof. ${ }^{a}$ Conceição Rodrigues.

A própria arquitetura do prédio indica que o pátio construído no centro fora planejado para atividades coletivas que abrigassem muita gente, pois, dessa forma, todas as salas de 
aulas davam para o pátio, permitindo assim a rápida circulação de grande número de pessoas, bem como a acomodação destes de maneira rápida, pois não demandaria grandes deslocamentos entre as salas de aula e o espaço de encontro.

A instituição escolar, por ela mesma, é um lugar que reproduz as conveniências sociais $^{46}$, de maneira que uma de suas funções é afastar do cotidiano os comportamentos transgressores e desviantes das normas sociais. No contexto em análise, a EASAR era a instituição que cumpria esse papel perante a sociedade em que fora implantada.

Já para a ex-estudante Francisca Maria do Nascimento ${ }^{47}$, que participou da oficina de corte, costura e bordado, oficina direcionada apenas para o público feminino, não foram as festas que lhes saltaram a memória, mas outro serviço prestado pela escola à comunidade. De acordo ela, os melhores produtos confeccionados nas oficinas de serralheria, assim como os hortifrutos produzidos na horta da escola, eram comercializados na comunidade:

Tinham as meninas que já sabiam fazer mesmo, que já faziam já as coisas já por encomenda, entendeu? Aquelas que iam se destacando, tanto na costura, quanto no bordado, e aí eles iam até vendendo, botavam nessas feirinhas, as meninas iam pras feirinhas. [...] Aqui [em casa] tinham umas portas, antigamente, que foram feitas lá, que um dos meninos daqui estudavam lá na marcenaria, o Chico, e as portas foram feitas, daqui de casa, foram feitas lá, as primeiras portas daqui foram feitas lá. [...] Era vendido mais barato, eles faziam e a comunidade mesmo comprova, as verduras também eram vendidas, os meninos plantavam feijão também, vendiam para comunidade, era $\operatorname{assim}^{48}$.

Novamente, a escola aparece vinculada diretamente à vida dos moradores do bairro, em suas diferentes situações cotidianas, uma vez que à comunidade eram oferecidos os produtos feitos na escola. A família da ex-estudante foi uma das beneficiadas com lotes de terra que foram vendidos pela escola para alguns dos sitiantes daquela região e para funcionários da escola, como a sua já falecida mãe, Elvira Nascimento ${ }^{49}$, trabalhava na limpeza da instituição. Ela foi também uma das pessoas que conseguiram financiar um lote de terra próprio para morar, sendo que, como relatado na memória de Francisca, até algumas portas da casa construída naquele terreno foram produzidas por um de seus irmãos durante o curso de marcenaria que este frequentava na Escola Santo Afonso Rodriguez.

A EASAR contribuiu tanto para a oferta de ensino formal quanto profissional, além de contribuir para a fixação de residência dos moradores em terrenos loteados pela escola. Essa instituição de ensino também foi responsável pelo aumento na oferta de serviços básicos e culturais prestados à comunidade que vivia em seu entorno durante as décadas de 1960 e 1970, sendo lembrada pelos estudantes e seus familiares como um local de oportunidades para a comunidade da região. 


\section{Considerações finais}

Neste trabalho, recorremos à análise dos relatos de antigos estudantes da Escola Santo Afonso Rodriguez e moradores do atual bairro Socopo como fragmentos de memória que evidenciam práticas cotidianas e coletivas do local, quando ainda era um povoado da zona rural de Teresina. Essas memórias refletem, como em um prisma, uma perspectiva de vida e do viver naquela área durante as décadas de 1960 e 1970, indicando como a história dessa escola foi de fundamental relevância para a elevação do povoado posteriormente em bairro, na capital do Piauí. Elas também versam sobre a presença e a influência da Companhia de Jesus exercida sobre os moradores do povoado, principalmente porque a Escola Santo Afonso Rodriguez foi mencionada pelos entrevistados como tendo sido uma instituição essencial para a vida de cada um, mas também para a própria história da expansão da cidade de Teresina rumo à zona leste.

Os jesuítas faziam parte do convívio cotidiano das pessoas que viviam no seu entorno, principalmente junto àqueles que moravam na comunidade Socopo, seja porque essas pessoas trabalhavam na escola, seja porque muitos tinham filhos matriculados nela. A influência da escola na vida dos estudantes foi inquestionável, uma vez que muitos dos matriculados passavam o dia nas suas dependências, em regime de semi-internato, e, portanto, tendo acesso a um ensino jesuítico durante a sua formação escolar básica, sendo esse ensino, então, voltado, sobremaneira, para a formação profissional desses estudantes. Isso influenciou os caminhos que cada estudante seguiu em sua vida e os próprios percursos da comunidade.

De acordo com os significados atribuídos pelos moradores da região, são inegáveis as contribuições proporcionadas pela escola à vida de cada um e da própria comunidade, sobretudo em seus primeiros anos de funcionamento. Desse modo, destacam-se a própria fixação de muitos moradores, devido à aquisição de terrenos que viriam a se tornar a comunidade Socopo, além da formação escolar, profissional e religiosa proporcionada pela instituição de ensino, responsáveis por transformações no seio social da região leste de Teresina.

Por isso, consideramos válido afirmar que dentre, os objetivos dessa escola, ressaltam-se os educacionais e missionários, embora a instalação e a atuação da instituição de ensino filantrópica não tenha se restringido a tentar operacionaizar o lema da Companhia de Jesus: "Em tudo amar e servir", mas influenciou todo o contexto social da região onde a escola foi instalada, contribuindo sobremodo com a ampliação do espaço físico da cidade em 
direção à zona leste da capital, onde estavam situados os prédios da Companhia de Jesus no povoado Socopo.

Defendemos que a atuação dos jesuítas foi fundamental para a fixação de expressiva parcela da população naquela região, sendo, portanto, decisiva no processo de formação e expansão territorial e social da cidade em direção à zona leste, entre as décadas de 1960 e 1970, além de contribuir de maneira expressiva para a valorização imobiliária que a região passou a ter desde então, a ponto de passar a ser denominada como "zona nobre" da cidade, tornando-se uma das áreas mais cobiçadas de Teresina.

Dessa forma, a Escola Santo Afonso - instituição ainda em funcionamento no ano de 2020 - é imprescindível para entender a própria história recente de Teresina, sobretudo por ter marcado de forma indelével a vida de sua população, o que é exposto de forma vívida nos relatos orais emitidos na presente pesquisa.

\section{Notas}

\footnotetext{
${ }^{1}$ Esta frase é o lema adotado pela Companhia de Jesus em suas atuações, que se inspiraram nos ensinamentos de Inácio de Loyola, fundador da ordem religiosa. Este também é o lema das escolas jesuítas que foram implantadas no Brasil, a exemplo da Escola Santo Afonso Rodrigues, instituição de caráter filantrópico, instalada na zona leste de Teresina, na década de 1960.

${ }^{2}$ Religioso eleito pela Congregação para coordenar as atividades jesuítas no Brasil, à época, Padre Pedro Dalle Nogare.

${ }^{3}$ O Colégio Diocesano foi fundado em 1906 pelo primeiro bispo da Diocese do Piauí, Dom Joaquim Antônio D'Almeida, a princípio na instituição funcionava como colégio e seminário. Desde sua fundação, o colégio tem sede ao lado da praça Saraiva, local onde permanece até os dias atuais. Durante o governo de Dom Otaviano Pereira, segundo bispo do Piauí, o colégio foi fechado, pois a diocese alegava falta de recursos para mantê-lo em pleno funcionamento. Ao assumir a diocese, em 1924, Dom Severino Vieira de Melo reabriu as portas do colégio, e desde então, o nomeou como Colégio São Francisco de Sales, a partir desse período funcionaria em regime de internato, semi-internato e externato. No período entre 1954 e setembro de 1959, a instituição fora dirigida pelo Pe. Deusdete Craveiro, que decidiu encerrar com o regime de internato e semi-internato, tendo se tornado o último diretor diocesano da instituição, pois de outubro de 1959 até o início de 1960, quando o colégio passou a ser administrado pela Companhia de Jesus, o colégio teve seu primeiro diretor leigo, o professor de matemática Bernardo Lopes de Sousa. Ver em: CARVALHO JR, Dagoberto. História Episcopal do Piauí. Teresina: Academia Piauiense de Letras. 1980.

${ }^{4}$ GRAZZIOTIN, Luciane Sgarbi Santos; KLAUS, Viviane. Entre Tradição e Inovação: percursos da história da educação de uma instituição jesuíta (Unisinos - 1953-2016). Revista Educação e Realidade. Porto Alegre: v.41, n. especial, dez. 2016. p. 1485.

${ }^{5}$ BÉDARIDA, François. Tempo presente e presença da história. In: AMADO, Janaína; FERREIRA, Marieta de Moraes (Orgs). Usos \& abusos da história oral. Rio de janeiro: Editora: FGV, 2006. p. 224.

${ }^{6}$ LOPES, Antônio de Pádua Carvalho. Os discursos em torno do retorno dos jesuítas ao Piauí na década de 1960: o Colégio Diocesano entre continuidades e rupturas. In: SOUSA, Carlos Ângelo de Meneses Sousa; CAVALCANTE, Maria Juraci Maia. Os jesuítas no Brasil: entre a Colônia e a República. Brasília: Unesco, 2016. p. 272.

${ }^{7}$ PEREIRA, Luciana de Lima. A Igreja Católica em "tempos mundanos": a luta pela construção de uma Neocristandade em Teresina (1948-1960). Dissertação - Mestrado em História do Brasil, UFPI. Teresina, 2008. p. 14.

${ }^{8}$ O Colégio Sagrado coração de Jesus foi fundado em 1906, como iniciativa do recém-instalado bispado do Piauí que naquele momento procurava contrapor o ensino católico ao ensino leigo. Voltado para a absorção do alunado
} 
feminino, desde o ano de 1914 funciona em prédio instalado na Avenida Frei Serafim. Ver em QUEIROZ, Teresinha. Educação no Piauí (1880-1930). Imperatriz: Ética, 2008. p. 67 e 68.

${ }^{9}$ Concílio no qual foram realizadas conferências no Vaticano, entre os anos de 1962 e 1965. Os diversos temas deliberados e repensando pela Igreja (os ritos da missa, vestimenta dos padres, relações com outras religiões, etc) foram propostos com a intenção de que a instituição se libertasse da sua carga tradicional e com isso conseguisse elaborar uma nova atuação no mundo moderno, que, então, respondesse aos anseios do homem urbano.

${ }^{10}$ BOFF, Leonardo. Igreja: carisma e poder. Petrópolis: Vozes, 1981. p. 22.

${ }^{11}$ Alagoano, nascido em 13 de junho de 1912, com 23 anos ordenou-se Padre na cidade de Aracaju, onde, por 11 anos, exerceu diversos cargos, desde professor e secretário do Bispado à diretor espiritual do seminário Sagrado Coração de Jesus. Em 1946, foi eleito Bispo de Petrolina, onde atuou por uma década, até ser elevado à condição de segundo arcebispo da Arquidiocese de Teresina em 1956, cargo que permaneceu até maio de 1971. Após esse período, fora residir em Salvador, sede primacial da Igreja Católica no Brasil, até que em fevereiro de 1973, fora escolhido pelo Papa VI como cardeal da Igreja de Roma. Sobre a biografia e atuação de Dom Avelar em Teresina, sugerimos as seguintes leituras: ARAÚJO, Warrington Wallace Veras de. Dom Avelar Brandão Vilela, entre o texto e o contexto: trajetórias e representações do arcebispo do Piauí (1956-1971). Dissertação -

Mestrado em História do Brasil, UFPI. Teresina, 2008. CARVALHO, Sônia Maria dos Santos. O bispo de todos os tempos: uma biografia de Dom Avelar Brandão Vilela. Teresina: EDUFPI, 2013. PEREIRA, Luciana de Lima. A Igreja Católica em "tempos mundanos": a luta pela construção de uma Neocristandade em Teresina (1948-1960). Dissertação - Mestrado em História do Brasil, UFPI. Teresina, 2008.

${ }^{12}$ CUNHA E SILVA. Ideia Feliz. O Dia, Teresina, 31 de janeiro de 1960. № 718. Ano IX. p. 06.

${ }^{13}$ Idem. p.06.

${ }^{14}$ Da esquerda para direita: Pe. Moisés Fumagalli, Pe. Carlo Bresciani, ao fundo: Ir. Luís Óboe e Pe. Luciano Cimamn.

${ }^{15}$ COLÉGIO DIOCESANO SÃO FRANCISCO DE SALES. Diocesano: 90 anos educando para a beleza da paz (1906-1996). Teresina. 1996. p. 56.

${ }^{16}$ É comum às ordens religiosas procurarem refúgio em zonas afastadas da cidade, onde possam ter um local amplo e tranquilo para realizarem suas atividades. Discorrendo sobre essa relação entre subúrbio e cidade na história das ordens mendicantes na Europa, Jacques Le Goff propõe que a escolha pelo subúrbio (periferia, zona rural) não deixa de ter uma intenção de ser, segundo o mesmo: "No século XIII, parecia essencial a essas ordens fazerem-se aceitas dando as populações o exemplo da pobreza e da humildade, elas extraem as lições dos movimentos sociais que estão emergindo, nos quais as pessoas simples da cidade questionam a atitude dos poderosos e, em particular, a dos senhores, os quais, de seu campo, de suas fortalezas, continuam a dominar o espaço, incluindo o espaço urbano. Em contraposição, a riqueza se cria de modo ainda mais brutal na cidade, com os mercadores, os burgueses, o comércio. Diante da arrogância dos novos ricos e dos antigos poderosos que estão sempre aí, para convencer o povo, para não deixá-los rebelar-se contra a ideologia cristã da épocaperdoem-me a expressão- essas novas ordens mendicantes querem dar o exemplo. É essa mesma a expressão que eles empregam: "pregar o exemplo". Como então eles concebem sua inscrição no espaço? Eles chegam a uma cidade, fala-se deles, são novos personagens que provocam certa curiosidade. Mas eles ainda não adquiriram prestígio nem poder e, além disso, empenham-se em pôr em prática os ideais que pregam. Onde vão se estabelecer então? No limite da cidade. E com frequência fora dela, na proximidade de suas portas. Onde o terreno é barato, onde muitas vezes recebem de presente uma casa ou um lote de terra. (...) Os mendicantes, portanto, encontram-se modestamente instalados na periferia, perto da muralha, no interior, mas às vezes também no exterior da cidade. Eles manifestam assim o caráter subordinado e pobre do subúrbio com relação à cidade e ao centro da cidade. E o que acontece em seguida? Rapidamente, (...), tornam-se conhecidos, estimados e poderosos". Ver em LE GOFF, Jacques. Por amor às cidades: conversações com Jean Lebrun- São Paulo: Fundação editora da UNESP, 1998. p. 17-22. Sabemos que não estamos tratando das ordens mendicantes nascentes no final da Idade Média, mas a análise mencionada nos ajuda a iluminar o caso dos Jesuítas no Piauí, que por estarem retornando suas atividades no Estado, que haviam sido cessadas desde a expulsão feita no governo Pombalino, estavam em busca de fiéis, de homens e mulheres que lhes acompanhassem no ideal de seguir a Cristo.

${ }^{17}$ OLIVEIRA, Stanley Braz de. A Geo-história de Teresina na perspectiva das ações da Igreja católica, no âmbito da educação: 1903-1963. Tese (Doutorado em Geografia) - Universidade Estadual do Ceará. Fortaleza, 2014. p. 123 e 153.

${ }^{18}$ Em sua pesquisa, Stanley Braz de Oliveira procurou elaborar uma Geo-história do Colégio das Irmãs e do Colégio Diocesano. Seu argumento é o de que ambas as escolas, quando foram fundadas, por volta dos primeiros anos do século XX, foram construídas em espaços pouco habitados da cidade de Teresina e que após a consolidação da ação educacional os espaços que ficavam em seus entornos passaram a se desenvolver amplamente. Portanto, o autor infere que a Igreja Católica deva ser vista como um agente produtor da cidade, 
tendo em vista que ao escolher a localização onde instalariam ambas as escolas, a Igreja estaria produzindo o espaço urbano de acordo com os seus interesses. Tanto para o autor, como por nós, esse entendimento deve ser aplicado também ao caso da Escola Santo Afonso Rodriguez.

${ }^{19}$ Idem, p. 122.

${ }^{20}$ CARLOS, Ana Fani Alessandri. A cidade. São Paulo: Contexto. 9a ed. 2018. p. 48.

${ }^{21}$ NORA, Pierre. Entre Memória e história: a problemática dos lugares. Projeto História: Revista do Programa de Estudos Pós-Graduados em História do Departamento de História da PUC-SP. São Paulo, 1984. p. 14.

${ }^{22}$ Idem, p. 12.

${ }^{23}$ RICEEUR, Paul. A memória, a história, o esquecimento. Campinas: SP: Editora da UNICAMP, 2007. p. 416.

${ }^{24}$ Teresinha da Silva Coutinho atualmente é aposentada, quando da realização da entrevista tinha 74 anos e trabalhou como costureira desde a sua vinda para a comunidade Socopo.

${ }^{25}$ COUTINHO. Teresinha da Silva. Entrevista concedida a Viviam Cathaline de Sousa Ferreira. Teresina, 23 de outubro de 2015.

${ }^{26}$ Francisco Coutinho de Sousa é proprietário de uma marcenaria no bairro Socopo, quando da realização da entrevista tinha 54 anos.

${ }^{27}$ SOUSA, Francisco Coutinho de. Entrevista concedida a Víviam Cathaline de Sousa Ferreira. Teresina. 23 de junho de 2016.

${ }^{28}$ BACELLAR, Olavo Ivahoé de B; LIMA, Gerson Portela. Causas e tendências do processo migratório piauiense. Teresina, Fundação CEPRO, 1990. p. 29.

${ }^{29}$ COUTINHO, Teresinha da Silva. Entrevista concedida a Viviam Cathaline de Sousa Ferreira. Teresina, 23 de outubro de 2015.

${ }^{30}$ SOUSA, Francisco Coutinho de. Entrevista concedida a Víviam Cathaline de Sousa Ferreira. Teresina. 23 de junho de 2016.

${ }^{31}$ Idem.

${ }^{32}$ Jesuíta italiano, que era o responsável pela administração dos bens por todas as atividades exercidas na escola durante o recorte de tempo escolhido na pesquisa.

${ }^{33}$ SOUSA, Francisco Coutinho de. Entrevista concedida a Víviam Cathaline de Sousa Ferreira. Teresina. 23 de junho de 2016.

${ }^{34}$ LEFEBVRE, Henri. $O$ direito à cidade. São Paulo: Centauro, 2001. p. 73.

${ }^{35}$ Nesta pesquisa, apropriamo-nos do conceito de paisagem urbana exposto por Ana Fani Alessandri Carlos, a qual infere que a "paisagem não é só produto da história como também reproduz a história, a concepção que o homem tem e teve do morar, do habitar, do trabalhar, do comer e do beber, enfim do viver". E continua, ao afirmar que a paisagem "não é estática, mas prenhe de movimento, de vida, de uma vida rica de relações que o homem (o indivíduo) mantém dia após dia para se reproduzir enquanto ser humano, membro de uma sociedade e enquanto espécie". Ver em CARLOS, Ana Fani Alessandri. A cidade. São Paulo: Contexto. 9a ed. 2018. p. 38.

${ }^{36}$ SOUSA, Francisco Coutinho de. Entrevista concedida a Viviam Cathaline de Sousa Ferreira. Teresina. 23 de junho de 2016.

${ }^{37}$ ALBERTI, Verena. Ouvir Contar: textos em História Oral. Rio de Janeiro: Editora FGV, 2004. p. 16.

38 TERESINA. Secretaria Municipal de Planejamento e Coordenação. Plano de Desenvolvimento Local Integrado de Teresina. 1969.

${ }^{39}$ SOUSA, Francisco Coutinho de. Entrevista concedida a Víviam Cathaline de Sousa Ferreira. Teresina. 23 de junho de 2016.

${ }^{40}$ Professora da instituição desde 1970, atualmente atua como Pastoralista, função na qual exerce conversas e orientações educacionais e religiosas com os estudantes da instituição. Também nos cedeu todas as fotografias utilizadas na realização dessa pesquisa, afinal, por muitos anos foi a responsável por fotografar os eventos realizados na instituição.

${ }^{41}$ COUTINHO, Teresinha da Silva. Entrevista concedida a Viviam Cathaline de Sousa Ferreira. Teresina, 23 de outubro de 2015.

${ }^{42}$ Vilani de Sousa Mota viveu toda a sua vida no bairro Socopo, filha de migrante que veio residir na região em 1970, atuou como Agente de Saúde Comunitária no bairro até o ano de 2018. Quando da entrevista tinha 41 anos de idade.

${ }^{43}$ MOTA, Vilani de Sousa. Entrevista concedida a Víviam Cathaline de Sousa Ferreira. Teresina, 19 de junho de 2016.

${ }^{44}$ Idem.

${ }^{45}$ Idem.

46 “A conveniência é o gerenciamento simbólico da face pública de cada um de nós desde que nos achamos na rua. A conveniência é simultaneamente o modo pelo qual se é percebido e o meio obrigatório de se permanecer submisso a ela: no fundo, ela exige que se evite toda dissonância no jogo dos comportamentos, e toda ruptura 
qualitativa na percepção do meio social. Por isso é que produz comportamentos estereotipados, "prêt-à-porter" sociais, que têm por função possibilitar o reconhecimento de não importa quem em não importa que lugar". Ver em: MAYOL. Pierre. O bairro. In: CERTEAU, Michel de. A invenção do cotidiano: 2. Morar, cozinhar. Petrópolis, RJ: Vozes, 1996. p. 49.

${ }^{47}$ Francisca Maria do Nascimento lembra que reside no bairro desde sua infância, atualmente trabalha como auxiliar de administração em uma faculdade particular de Teresina, quando a entrevista foi realizada possuía 51 anos de idade.

${ }^{48}$ NASCIMENTO, Francisca Maria do. Entrevista concedida a Viviam Cathaline de Sousa Ferreira. Teresina, 25 de junho de 2016.

${ }^{49}$ Elvira Nascimento, falecida, trabalhou como secretária na Escola Santo Afonso Rodriguez entre meados dos anos 1970 até finais dos anos 1980. Sua família foi uma das que adquiriu um lote de terra por intermédio da venda realizada pela escola.

\section{Referências}

ALBERTI, Verena. Ouvir Contar: textos em História Oral. Rio de Janeiro: Editora FGV, 2004.

BACELLAR, Olavo Ivahoé de B; LIMA, Gerson Portela. Causas e tendências do processo migratório piauiense. Teresina, Fundação CEPRO, 1990.

BÉDARIDA, François. Tempo presente e presença da história. In: AMADO, Janaína; FERREIRA, Marieta de Moraes (Org.). Usos \& abusos da história oral. Rio de janeiro: Editora: FGV, 2006.

BOFF, Leonardo. Igreja: carisma e poder. Petrópolis: Vozes, 1981.

CARLOS, Ana Fani Alessandri. A cidade. São Paulo: Contexto. 9ª ed. 2018.

CARVALHO JR., Dagoberto. História Episcopal do Piauí. Teresina: Academia Piauiense de Letras. 1980.

CERTEAU, Michel de. A invenção do cotidiano: 2. Morar, cozinhar. Petrópolis, RJ: Vozes, 1996.

COLÉGIO DIOCESANO SÃO FRANCISCO DE SALES. Diocesano: 90 anos educando para a beleza da paz (1906-1996). Teresina. 1996.

COUTINHO, Teresinha da Silva. Entrevista concedida a Viviam Cathaline de Sousa Ferreira. Teresina, 23 de outubro de 2015.

CUNHA E SILVA. Ideia Feliz. O Dia, Teresina, 31 de janeiro de 1960. № 718. Ano IX. p. 06.

GHIRALDELLI JR., Paulo. História da educação brasileira. 4ª ed. São Paulo: Cortez, 2009.

GRAZZIOTIN, Luciane Sgarbi Santos; KLAUS, Viviane. Entre Tradição e Inovação: percursos da história da educação de uma instituição jesuíta (Unisinos - 1953-2016). Revista Educação e Realidade. Porto Alegre: v.41, n. especial, dez. 2016. p. 1485-1506. 
JULIA, Dominique. A Cultura Escolar como Objeto Histórico. Revista brasileira de História da Educação. Campinas: v. 01, n. 1, 2001.

LEFEBVRE, Henri. O direito à cidade. São Paulo: Centauro, 2001.

LE GOFF, Jacques. Por amor às cidades: conversações com Jean Lebrun. São Paulo: Fundação editora da UNESP, 1998.

LOPES, Antônio de Pádua Carvalho. Os discursos em torno do retorno dos jesuítas ao Piauí na década de 1960: o Colégio Diocesano entre continuidades e rupturas. In: SOUSA, Carlos Ângelo de Meneses Sousa; CAVALCANTE, Maria Juraci Maia. Os jesuítas no Brasil: entre a Colônia e a República. Brasília: Unesco, 2016.

MOTA, Vilani de Sousa. Entrevista concedida a Víviam Cathaline de Sousa Ferreira. Teresina, 19 de junho de 2016.

NASCIMENTO, Francisca Maria do. Entrevista concedida a Viviam Cathaline de Sousa Ferreira. Teresina, 25 de junho de 2016.

NORA, Pierre. Entre Memória e história: a problemática dos lugares. Projeto História: Revista do Programa de Estudos Pós-Graduados em História do Departamento de História da PUC-SP. São Paulo, 1984.

OLIVEIRA, Stanley Braz de. A Geo-história de Teresina na perspectiva das ações da Igreja católica, no âmbito da educação: 1903-1963. Tese (Doutorado em Geografia) - Universidade Estadual do Ceará. Fortaleza, 2014.

PEREIRA, Luciana de Lima. A Igreja Católica em "tempos mundanos": a luta pela construção de uma Neocristandade em Teresina (1948-1960). Dissertação - Mestrado em História do Brasil, UFPI. Teresina, 2008.

QUEIROZ, Teresinha. Educação no Piauí (1880-1930). Imperatriz, MA: Ética, 2008.

RICCEUR, Paul. A memória, a história, o esquecimento. Campinas: SP: Editora da UNICAMP, 2007.

SOUSA, Francisco Coutinho de. Entrevista concedida a Víviam Cathaline de Sousa Ferreira. Teresina. 23 de junho de 2016.

TERESINA. Secretaria Municipal de Planejamento e Coordenação. Plano de Desenvolvimento Local Integrado de Teresina. 1969. 